University of Wollongong

Research Online

Faculty of Law, Humanities and the Arts Papers (Archive)

Faculty of Arts, Social Sciences \& Humanities

$1-1-2013$

Rampant food adulteration in Bangladesh: Gross violations of fundamental human rights with impunity

S M. Solaiman

University of Wollongong, sheikh@uow.edu.au

Abu Noman Mohammad Atahar Ali

University of Wollongong, anmaa@uow.edu.au

Follow this and additional works at: https://ro.uow.edu.au/lhapapers

Part of the Arts and Humanities Commons, and the Law Commons

Research Online is the open access institutional repository for the University of Wollongong. For further information contact the UOW Library: research-pubs@uow.edu.au 


\title{
Rampant food adulteration in Bangladesh: Gross violations of fundamental human rights with impunity
}

\begin{abstract}
Food adulteration in Bangladesh is rampant and an increasingly serious concern for its residents. Several studies including those of the Directorate General of Health Services reveal that hundreds of people are getting killed every year eating adulterated foodstuffs and no one seems to have any real concern about such a life-threatening wrongful act. Food adulteration is criminally prohibited, but the wrongdoers care little about this proscription simply because of the continued apathy of the governmental agencies concerned and implicit acceptance or insensible ignorance of consumers. However, the current fragmented legal and regulatory regime for food safety in Bangladesh falls short of international standards. This article demonstrates that the Government of Bangladesh is obliged to prevent food adulteration and to punish perpetrators under its international as well as constitutional obligations. It is also submitted that effective regulation of such an endemic malfeasance entails weakening the offenders by adopting international standards and educating the consumers at the same time.
\end{abstract}

\section{Keywords}

food, adulteration, rampant, bangladesh, impunity, gross, violations, fundamental, human, rights

\section{Disciplines}

Arts and Humanities | Law

\section{Publication Details}

S. M. Solaiman and A. Ali, 'Rampant food adulteration in Bangladesh: Gross violations of fundamental human rights with impunity' (2013) 14 (1-2) Asia Pacific Journal on Human Rights and the Law 29-65. 
Rampant Food Adulteration in Bangladesh: Gross Violations of Fundamental Human Rights with Impunity

\author{
S M Solaiman, PhD (UOW), LLM (UWS) LLM (DU) LLB Hons (RU) \\ Senior Lecturer \\ School of Law \\ University of Wollongong \\ NSW 2522, Australia \\ Email:sheikh@uow.edu.au \\ and
}

Abu Noman Mohammad Atahar Ali, LLM, LLB Hons (IU)

PhD Candidate

School of Law

University of Wollongong

NSW 2522, Australia

Email: anmaa964@uowmail.edu.au 


\title{
Rampant Food Adulteration in Bangladesh: Gross Violations of Fundamental Human Rights with Impunity
}

\author{
S M Solaiman* \\ Abu Noman Mohammad Atahar Ali**
}

\begin{abstract}
Food adulteration in Bangladesh is rampant and an increasingly serious concern for its residents. Several studies including those of the Directorate General of Health Services reveal that hundreds of people are getting killed every year eating adulterated foodstuffs and no one seems to have any real concern about such a life-threatening wrongful act. Food adulteration is criminally prohibited, but the wrongdoers care little about this proscription simply because of the continued apathy of the concerned governmental agencies and implicit acceptance or insensible ignorance of consumers. However, the current fragmented legal and regulatory regime for food safety in Bangladesh falls short of international standards. This article demonstrates that the Government of Bangladesh is obliged to prevent food adulteration and punish perpetrators under its international as well as constitutional obligations. It also submits that effective regulation of such an endemic malfeasance entails weakening the offenders by adopting international standards and educating the consumers at the same time.
\end{abstract}

\section{A. Introduction}

The right to life is the nucleus of all other rights regardless of any boundaries, whilst the right to consume 'safe food"1 is integral to human lives. Bangladesh, a third world country, has long been facing acute problem concerning food safety. From a human rights perspective, Bangladesh has many issues to deal with, including an unacceptable level of child mortality, extra judicial killing, custodial torture and so forth. Accordingly, public media and the human rights watchdog in the country are continually focusing on these issues in order to bring them to the notice of respective national authorities and international communities. But the concern or food safety has not been the subject of much attention so far, compared to other human rights issues. Hence, although the ongoing massive food adulteration has turned to be a silent

\footnotetext{
* S M Solaiman, PhD (UOW), LLM (UWS) LLM (DU) LLB Hons (RU), Senior Lecturer, School of Law, University of Wollongong, NSW 2522, Australia, Email: sheikh@uow.edu.au

** Abu Noman Mohammad Atahar Ali, LLM, LLB Hons (IU), PhD Candidate, School of Law, University of Wollongong, NSW 2522, Australia, Email: anmaa964@uowmail.edu.au

${ }^{1}$ Although this article focuses on 'the right to safe food' as part of international human rights, this right has been hardly explored in human rights legal scholarships. See Stefania Negri, 'Food Safety and Global Health: An International Law Perspective’ (2009) 3 (1) Global Health Governance 1, 3; see also Zhao Rongguang and George Kent, 'Human Rights and the Governance of Food Quality and Safety in China' (2004) 13(2) Asia Pacific Journal of Clinical Nutrition 178, 180-1.
} 
killer for 160 million population of the country, the issue remains to be largely ignored by both national and international media and the human rights watchdog as a human rights concern.

This article intends to demonstrate the violation of the right to safe food as part of the right to life and right to food (RLRF) and its impacts on public health and lives in Bangladesh. It examines the present status of the RLRF in light of the relevant international human rights instruments and the Constitution of Bangladesh (Constitution). It looks into the legal responsibilities of the governmental authorities with respect to ensuring food safety. This study finds that wrongdoers are taking advantage of regulatory laxities as the government is turning a blind eye to the casualties of adulterated and poisonous foodstuffs in breach of its constitutional as well as international obligations. It submits by way of conclusion that the Government of Bangladesh needs to pay adequate attention to the regulation of food adulteration which has been a major cause of numerous deaths and immense human suffering in the poor country. It emphasises the need to comply with the national and international binding obligations of the government by strengthening the legal and enforcement regime for food safety.

\section{B. Human Rights and Fundamental Rights}

There are two words in the phrase - 'human' and 'rights'. The word 'human' refers to any individual human being who is fundamentally an independent natural person as well as a citizen of a state. ${ }^{2}$ The word 'right' signifies different legal entitlements and relationships such as privilege, safety, immunity and even power. ${ }^{3}$

\footnotetext{
${ }^{2}$ M Rafiqul Islam, 'The Universal Declaration of Human Rights: A Searching Reappraisal of Its Continuing Validity after Sixty Years of Proclamation' in Mizanur Rahman (ed), Human Rights: 60 Years after UDHR (Empowerment Through Law of the Common People \& Palal Prokashini, 2008) 1, 3.

${ }^{3}$ Wesley Newcomb Hohfeld, 'Fundamental Legal Conceptions as Applied in Judicial Reasoning' (1914) 23 Yale Law Journal 16, 30. Hohfeld elsewhere also mentioned that "the word "right" is used generically and
} 
Human rights are generally defined as the rights that are natural, universal, inalienable and inherent to all human beings regardless of their nationality, race, sex, colour, culture, religion, ethnicity and social status. ${ }^{4}$ A person cannot explore his or her human nature without having to enjoy these rights. These rights are thus imperative to explore, flourish and build up human attributes and qualities. ${ }^{5}$ They are called 'birthright of all human beings' as people are entitled to enjoy them simply by virtue of their humanity, therefore those rights need not have to be granted or bestowed by an authority for them to be enjoyed. ${ }^{6}$ As mandated by the United Nations, everyone is entitled to enjoy their human rights without any discrimination whatsoever. ${ }^{7}$ The basic characteristics of human rights as set forth by the United Nations are that they are 'all interrelated, interdependent and indivisible'.

As different human rights are interconnected, the enjoyment of one right may entail the accessibility to other corresponding entitlements. ${ }^{9}$ For example, in a worst case scenario, if an individual is deprived of consuming safe food, he or she may get sick or badly affected by various food borne diseases which may eventually result in the deprivation of his/her right to of life. Conversely, the consumption of safe foods typically ensures a healthy and secured life. Hence, Clapham explains the human rights as those that need to be taken care of for one’s safety, dignity and human value. ${ }^{10}$

indiscriminately to denote any sort of legal advantage, whether claim, privilege, power, or immunity': Wesley Newcomb Hohfeld, 'Fundamental Legal Conceptions as Applied in Judicial Reasoning' (1917) 26 Yale Law Journal 710, 717.

${ }^{4}$ See Department of Foreign Affairs and Trade (DFAT), Australia, Human Rights Manual: 1993 International Year of the World's Indigenous People (Australian Government Publishing Service, 1993) 10; Lynn Hunt, 'The Paradoxical Origin of Human Rights' in Jeffrey N Wasserstom, Lynn Hunt and Marilyn B Young (eds), Human Rights and Revolutions (Rowman \& Littlefield Publishers, Inc, 2000) 3-4.

${ }^{5}$ Islam, above n 2, 3-4.

${ }^{6}$ DFAT, above n 4 .

${ }^{7}$ United Nations Human Rights (UNHR), What are Human Rights? (2012) Office of the High Commissioner for Human Rights, <http://www.ohchr.org/en/issues/Pages/WhatareHumanRights.aspx>.

${ }^{8}$ Ibid.

${ }^{9}$ Ibid.

${ }^{10}$ Andrew Clapham, Human Rights: A Very Short Introduction (Oxford University Press, 2007) 2. 
Fundament rights are, by definition, those that are protected and guaranteed by the national constitution. These rights are often termed as 'fundamental constitutional rights'. ${ }^{11}$ They are fundamental as they are enshrined in the constitution which is regarded as the supreme law of the land. ${ }^{12}$ Supporting this proposition, Goodpaster asserts that fundamental rights 'are fundamental essentially because they have important structural implications for the regulation of governmental power which other rights do not have; and that these rights may not be burdened except to protect against real and serious threats to the polity itself' ${ }^{13}$ Highlighting the importance of enjoyment of fundamental rights, the High Court Division of the Supreme Court of Bangladesh held in the State $v$ Deputy Commissioner Satkhira and Others that, it is the constitutional responsibility of the court to ensure that the fundamental rights of the citizens are preserved and well protected. ${ }^{14}$ Correspondingly, the Supreme Court of Bangladesh in Ain O Salish Kendra (ASK) \& Others v Government of Bangladesh \& Others pronounced that the state has a constitutional obligation to make effective provisions for securing the right to life, living and livelihood within its economic capacity. ${ }^{15}$

Although the fundamental rights have the higher status in the hierarchy of different legal rights recognised in a country, ${ }^{16}$ both human rights and fundamental rights are mutually inclusive. Perhaps the most salient feature of fundamental rights is that they are inviolable even by a piece of ordinary legislation because of the supremacy of the constitutional law. ${ }^{17}$

\footnotetext{
${ }^{11}$ For example, see Michael C Dorf, 'Incidental Burdens on Fundamental Rights' (1996) 109 Harvard Law Review 1175, 1176.

${ }^{12}$ See generally Laurence H Tribet and Michael C Dorf, 'Levels of Generality in the Definition of Rights' (1990) 57 University of Chicago Law Review 1057, 1057. The Constitution of Bangladesh is the supreme law of the land under article 7.

${ }^{13}$ Gary S Goodpaster, 'The Constitution and Fundamental Rights' (1973) 15 Arizona Law Review 479, 519.

${ }^{14}$ (1994)14 BLD (HCD) 266.

${ }^{15}$ (1999)19 BLD (HCD) 488.

${ }^{16}$ Robert Alexy, A Theory of Constitutional Rights (Oxford University Press, 2010) xix [translated by Julian Rivers].

${ }^{17}$ David A J Richards, The Moral Criticism of Law (Dickenson Publishing, 1977) 39-56; David A J Richards, 'Sexual Autonomy and the Constitutional Right to Privacy: A Case Study in Human Rights and the Unwritten Constitution' (1978-1979) 30 Hastings Law Journal 957, 958. See also Paul Brest, 'The Fundamental Rights Controversy: The Essential Contradictions of Normative Constitutional Scholarship' (1981) 90 Yale Law Journal 1063, 1075.
} 
Asserting the superiority of fundamental rights, the US Supreme Court in Boyd and Others v United States held more than a century ago that '[i]t is the duty of courts to be watchful for the constitutional rights of the citizen, and against any stealthy encroachments thereon’. ${ }^{18}$

The above discussion briefly presents a conceptual understanding of human rights and fundamental freedoms. It demonstrates that a state must protect these rights of its people. Any deviation from such a state responsibility would tantamount to breach of its duty and therefore it should attract condemnation of both national and international communities.

\section{Foods Adulteration and Its Deadly Effects on People in Bangladesh}

Food safety is a grave concern in Bangladesh which has been facing the problem of rampant food adulteration and unsafe attitudes towards food consumption for decades. This problem persists by and large at every level of foodstuffs from preparation to consumption. Food manufacturers, restaurants, food courts, organisational cafeterias, dining halls, fast food outlets and so forth are all involved in one way or another in this corrupt practice of adulteration. Foods are adulterated by using various harmful chemicals and toxic artificial colours on the one hand; and rotten perishables turning to be poisonous foods are stored, sold and served to consumers in an unhygienic atmosphere on the other. ${ }^{19}$ Supermarkets overtly

\footnotetext{
18116 US 616, 635 (1886) per Justice Bradley as quoted in William J Brennan, Jr, 'State Constitutions and the Protection of Individual Rights' (1977) 90 Harvard Law Review 489, 494.

${ }^{19}$ See, eg, Staff Correspondent, '2 Illegal Lube Factories Sealed Off in Chittagong', The Daily Star (online), 31 August $2005<$ <ttp://www.thedailystar.net/2005/08/31/d50831060355.htm>; Staff Correspondent, 'Food Adulteration: Mobile Court Faces Obstruction in Ctg', The Daily Star (online), 12 August 2005 <http://www.thedailystar.net/2005/08/12/d5081201033.htm>; Staff Correspondent, Rajshahi, '2 Fast Food Shops Fined', The Daily Star (online), 24 February $2010<$ http://www.thedailystar.net/story.php?nid=127700>; CU Correspondent, 'Anti-adulteration Drive: 2 Ctg Restaurant Owners Jailed', The Daily Star (online), 25 August $2006<$ http://www.thedailystar.net/2006/08/25/d60825100297.htm>; Correspondent, Ctg, 'Fake Mineral Water Factory Sealed Off', The Daily Star (online), 21 July 2006 $<$ http://www.thedailystar.net/2006/07/21/d60721061889.htm>; Imrul Hasan, 'Move to Maintain Food Quality in DU Canteens', The Daily Star (online), 18 September 2005 $<$ http://www.thedailystar.net/2005/09/18/d509182502112.htm>; Staff Correspondent, 'Traders Fined for Selling Toxic Chemicals as Food Colour', The Daily Star (online), 30 January 2007 <http://www.thedailystar.net/2007/01/30/d70130013625.htm>.
} 
sell fruits, fish and vegetables that have been treated with formalin and various other harmful substances. ${ }^{20}$ Manufacturers are adulterating foods when 'bulking' up a product by using dangerous material, for example by mixing husk with different cooking stuffs. ${ }^{21}$ Numerous incidents of such adulteration have been reported in the public media revealing seriously harmful approaches to production, storage and sale of foodstuffs. ${ }^{22}$ In Bangladesh, there are some famous branded food manufacturers and retailers who normally charge a higher price from consumers than their competitors for their foods as they claim their products are safe. But in a recent drive, the Dhaka City Corporation lab has found that, some of these prominent names like Agora, Acme Group, Premium Sweets, Golden Foods, Alauddin Sweets, Fakhruddin Biriani have massively produced and sold adulterated foodstuffs. ${ }^{23}$ In fact, the entire food industry seems to have been blatantly ignoring the existing food regulations in Bangladesh for ages, although some breaches resulted from ignorance, whilst most of them are deliberate. $^{24}$

\footnotetext{
${ }^{20}$ See, eg, Amin et al, 'Eating Away Our Health', The Daily Star, Weekend Magazine (online), 5 November 2004 <http://www.thedailystar.net/magazine/2004/11/01/cover.htm>; Staff Correspondent, 'RAB Seizes 24 Tonnes of Mangoes Mixed with Poisonous Chemicals', The Daily Star (online), 10 July 2008 $<$ http://www.thedailystar.net/story.php?nid=45073>; BSS, Rajshahi, 'Mango Ripened With Carbide Flood Markets', The New Nation (online), 23 May $2010<$ http://nation.ittefaq.com/issues/2010/05/23/news0623.htm>; Staff Correspondent, 'Formalin Fish Back in City Markets', The Daily Star (online), 1 March 2007 <http://www.thedailystar.net/2007/03/01/d7030101044.htm>.

${ }^{21}$ CU Correspondent, '3 Ctg Traders Fined', The Daily Star (online), 21 July 2008 $<$ http://www.thedailystar.net/story.php?nid=46736>.

${ }^{22}$ For example, see Iqbal Ahmed Sarkar, 'Plenty of Unapproved Adulterant Factories', The Daily Manab Zamin (Dhaka), 18 May 2011, last page [author's trans]; Gafargaon Correspondent, '50 Children Got Sick in Gafargaon Eating Chocolate', The Daily Manab Zamin (Dhaka), 26 September 2011, country news [author's tans]; 'Eleven Organisation Received Penalty for Three Lac Taka', The Prothom Alo (online), 11 August 2011 <http://www.prothom-alo.com/detail/date/2011-08-11/news/177171> [author's trans]; Jajadi Report, 'Great Festival of Adulteration! These Food Could Cause Long Term Health Problems', The Jai Jai Din (Dhaka), 10 August 2011, Mohanagar [author's trans]; Own Correspondent, 'Seven Organisations Got Fined One Lac and Seventeen Taka', The Prothom Alo (online), 25 August $2011<$ http://www.prothom-alo.com/detail/date/201108-25/news/180920> [author's trans]; Staff Reporter, 'Public Health Threatened: Laccha Vermicelli Manufactured in Tongi in Dirty Environment', The Daily Amar Desh (online), $<$ http://www.amardeshonline.com/pages/details/2011/08/19/100312> [author's trans].

${ }^{23}$ See Shawkat Ali Khan, 'Adulterated Foods on Sale in City amid Lax Monitoring', The New Age (online), 27 May 2009 <http://www.newagebd.com/2009/may/27/met.html>. In Bangladesh these mentioned companies are very famous food manufacturers and retailers.

${ }^{24}$ See, eg, S S M Sadrul Huda, Ahmed Taneem Muzaffar and Jasim Uddin Ahmed, 'An Enquiry into the Perception on Food Quality among Urban People: A Case of Bangladesh' (2009) 3(5) African Journal of Business Management 227, 228.
} 
The problems created by a lack of food safety have long been recognised. A survey conducted by the Institute of Nutrition and Food Science, University of Dhaka, in early 1980s had shown that inadequate diet and the intake of adulterated food are responsible for the malnutrition of 60 per cent of the people of Bangladesh. ${ }^{25}$ Ali observed that a lack of coordination of policies, laws, and administration is the main reason for the widespread violations of consumer protection regulations in Bangladesh. He added that the policies which aimed to prevent food adulteration could not be implemented due to a lack of effective legal and administrative mechanisms. ${ }^{26}$

The Institute of Public Health (IPH) - Dhaka and the World Health Organisation (WHO) in their 1994 study on food safety found that, all of the 52 street vendors' food samples were contaminated with different types of disease breeding micro-organisms. ${ }^{27}$ Another study of 2003 conducted by the same organisations as above in the capital city, Dhaka, revealed that amongst 400 sweetmeats, 250 biscuits, 50 breads and 200 ice creams samples, 96 per cent of sweetmeats, 24 per cent of biscuits, 54 per cent of breads, and 59 per cent of ice creams were adulterated. ${ }^{28}$ This 2003 study found that over the preceding decade, some 50 per cent of the food samples tested in IPH laboratory were adulterated. ${ }^{29}$

Every year many people fell sick by consuming unsafe foods around the world. Especially children are more vulnerable than adults as unsafe food is a major cause of child mortality as it was revealed in a report of the United Nations International Children Emergency Fund

\footnotetext{
${ }^{25}$ The Survey was cited in Quazi Mohammad Ali, 'Some Aspects of Consumer Protection in Bangladesh' (1984) Part-C The Dhaka University Studies 101, 111.

${ }^{26}$ Ibid 113.

${ }^{27}$ Neela Badrie, Sonia Y De Leon and Md Ruhul Amin Talukder, 'Food Safety Management Systems: Initiatives of Trinidad and Tobago, West Indies, Philippines and Bangladesh' (Paper presented at Caribbean Agro-Economics Society $26^{\text {th }}$ West Indies Agricultural Economic Conference, Puerto Rico, July 2006) 85 [4].

${ }^{28}$ Shah Mahfuzur Rahman, Md Asirul Hoque and Md Ruhul Amin Talukder, 'Food Security in Bangladesh: Utilization, Nutrition and Food Safety' (Paper presented at the National Workshop on Food Security, Dhaka, Bangladesh, 19-20 October 2005) 45-6.

${ }^{29}$ See, eg, ibid 46; Badrie, Leon and Talukder, above n 27; Amin et al, above n 20.
} 
(UNICEF) on child survival. ${ }^{30}$ It is universally accepted that an important factor of malnutrition is unsafe food, which causes various types of serious illnesses including diarrhoea and such foods have other permanent consequences for the human body. ${ }^{31}$ Hence, Bangladesh which has abundant adulterated foods cannot deny the contribution of unsafe foods for malnutrition. Powell asserts that proper handling of foodstuffs can indirectly remedy the nutrition problem, and contaminated foods can have a serious impact on public health. ${ }^{32}$ He adds that 'pesticides can also contaminate foods and provoke serious reactions when ingested. Chronic malnutrition can occur when bacteria, parasites, and even viruses are found in food sources on a regular basis'.33

The WHO report confirms that food safety causes at least three million premature deaths of children under five years of age worldwide, and that this has become a serious public and human rights concern in recent years. ${ }^{34}$ Certainly, it is one of the serious issues of the contemporary world, and it also has a considerable impact on the reduction of economic productivity. ${ }^{35}$ The developing countries, especially those in the South Asia, are at great risk in regard to issues related to food safety and under nutrition. ${ }^{36}$ WHO also warns that by 2025 , one person in four of the people aged 60 in developing countries will be at risk especially of food borne diseases. ${ }^{37}$

\footnotetext{
${ }^{30}$ United Nations International Children's Emergency Fund (UNICEF), The State of the World's Children 2008: Child Survival (2007) 1 <http://www.unicef.org/sowc08/docs/sowc08.pdf>.

${ }^{31}$ For details of the relation between food safety and malnutrition, see Motarjemi et al, 'Contaminated Weaning Food: A Major Risk Factor for Diarrhoea and Associated Malnutrition' (1993) 71(1) Bulletin of the World Health Organization 79.

32 Clydette Powell, 'Nutrition' in William H Markle, Melanie A Fisher and Raymond A Smego (eds), Understanding Global Health (McGraw-Hill Companies, 2007) 104, 122.

${ }^{33}$ Ibid.

34 Gro Harlem Brundtland, 'Food Safety: An Essential Public Health Issue for the New Millennium' (WHO/SDE/PHE/FOS/99.4, Food Safety Programme, Department of Protection of the Human Environment, World Health Organization, 1999)

$<$ http://www.who.int/foodsafety/publications/general/en/fos_brochure1999.pdf>.

${ }^{35}$ Ibid 3.

${ }^{36}$ See generally Figure 1.11 at UNICEF, above n 30, 11.

${ }^{37}$ Brundtland, above n 34, 1.
} 
Particularly, in Bangladesh, it is argued that many people die every year for reasons related to food safety, which is argued to be one kind of silent genocide. ${ }^{38}$ So this issue deserves to be addressed as a major concern of human life and health. The serious threat posed by the abundance of unsafe foods can be easily comprehended from the recent official statistics of the Government of Bangladesh. The statistics shown in a Table posted onto the website of the Ministry of Health and Family Welfare mentions the number of food samples tested by the IPH from 2001 to 2009, and demonstrates the distribution of the genuine and adulterated samples out of the total samples tested each year. ${ }^{39}$ The Table is reproduced below.

Table 1: Food Samples Tested from 2001 to 2009 by IPH.

\begin{tabular}{|c|c|c|c|c|c|}
\hline \multirow[t]{2}{*}{ Year } & \multirow{2}{*}{$\begin{array}{l}\text { Total } \\
\text { Samples }\end{array}$} & \multicolumn{2}{|c|}{ Genuine } & \multicolumn{2}{|c|}{ Adulterated } \\
\hline & & No. & $\%$ & No. & $\%$ \\
\hline 2001 & 3280 & 1692 & $51.6 \%$ & 1588 & $48.4 \%$ \\
\hline 2002 & 4300 & 2110 & $49.0 \%$ & 2190 & $51.0 \%$ \\
\hline 2003 & 5120 & 2515 & $49.1 \%$ & 2605 & $50.9 \%$ \\
\hline 2004 & 4413 & 2214 & $52.0 \%$ & 2119 & $48.0 \%$ \\
\hline 2005 & 6337 & 3200 & $50.5 \%$ & 3137 & $49.5 \%$ \\
\hline 2006 & 2779 & 1405 & $50.6 \%$ & 1374 & $49.4 \%$ \\
\hline 2007 & 5992 & 3488 & $58.2 \%$ & 2504 & $41.8 \%$ \\
\hline 2008 & 8734 & 5066 & $58.0 \%$ & 3668 & $42.0 \%$ \\
\hline 2009 & 6338 & 3356 & $52.9 \%$ & 2982 & $47.1 \%$ \\
\hline
\end{tabular}

\footnotetext{
${ }^{38}$ For details of the severity of unsafe food in Bangladesh, see FE Report, 'Speakers Liken Food Adulteration to Genocide', The Financial Express (online), 5 August $2010<$ http://www.thefinancialexpressbd.com/more.php?page=detail_news\&news_id=108092\&date=2010-08-05>.

${ }^{39}$ Government of the People's Republic of Bangladesh (Govt. of Bangladesh), Directorate General of Health Services (DGHS), Public Health Interventions by Selected Institutions (24 November 2010) $<$ http://nasmis.dghs.gov.bd/dghs_new/dmdocuments/All/Public\%20Health\%20Interventions.pdf>.
} 
The Table reveals that the situation of the prevailing food safety concerns in Bangladesh has not improved over the past 10 years. Rather, the situation is so unacceptable that the government appointed a Taskforce to find out the causes and consequences of unsafe food. A recent survey conducted by the National Taskforce on Food Safety (NTFS) discloses that unsafe food each year causes various food borne illnesses, including diarrhoea, malnutrition and other diseases leading to death of many people in Bangladesh. ${ }^{40}$ Alarmingly enough, the NTFS has recognised that diarrhoeal diseases have caused various disabilities of 5.7 million people in the country each year. ${ }^{41}$ Referring to the 1998 Annual Report of the International Centre for Diarrhoeal Disease Research, Bangladesh (ICDDRB), the NTFS mentioned that a total of 1657381 cases of acute diarrhoea and resultant deaths of 2064 lives occurred in 1998 alone. ${ }^{42}$ The NTFS report added that the treatment for hygiene related diseases in Bangladesh cost US\$80 million each year. ${ }^{43}$ The extent of attacks and deaths from diarrhoea has become frightening for the last couple of years in Bangladesh. The report of the Directorate General of Health Services (DGHS) mirrors the magnitude of the diarrhoeal diseases and confirms that this health problem is caused mainly by the unsafe foodstuffs. The following Table provides a statistics of the incidents of attacks and deaths by diarrhoeal disease in Bangladesh from 2003 to $2009 .^{44}$

Table 2: Year- wise Reported Diarrhoea Attacks and Deaths in Bangladesh

\begin{tabular}{|l|l|l|l|l|l|l|l|}
\hline Year & 2003 & 2004 & 2005 & 2006 & 2007 & 2008 & 2009 \\
\hline $\begin{array}{l}\text { Number of } \\
\text { Attacks }\end{array}$ & 2196919 & 2132434 & 2040927 & 1961850 & 2335326 & 2294979 & 5036849 \\
\hline
\end{tabular}

\footnotetext{
${ }^{40}$ National Taskforce on Food Safety, 'Bangladesh Country Paper’ (Paper presented at the FAO/WHO Regional Conference on Food Safety for Asia and Pacific, Seremban, Malaysia, 24-27 May 2004) 6.

${ }^{41}$ Ibid.

42 Ibid.

${ }^{43}$ Ibid, citing the Bangladesh Bureau of Statistics 1998 Handbook.

${ }^{44}$ DGHS, above n 39.
} 


\begin{tabular}{|l|l|l|l|l|l|l|l|}
\hline $\begin{array}{l}\text { Number of } \\
\text { Deaths }\end{array}$ & 1032 & 1067 & 694 & 239 & 537 & 393 & 712 \\
\hline
\end{tabular}

Although the number of deaths seems to be significantly lower than that of the actual attacks, thanks to the improvement of medical treatment under the auspices of various national and international initiatives, nonetheless the total deaths are still shocking. In addition to this worst consequence, food-borne illnesses like diarrhoea may have serious social and economic effects, including losses in productivity, income, income-generating capacity and resulted poverty. In support of this claim, an investigation of a group of researchers found that people who consume unsafe foods and/or suffer from food-borne diseases are less productive, and thus the profusion of adulterated foods contributes to reducing incomes, lessening access to safe foods and increasing food insecurity. ${ }^{45}$

Given the numerous deaths and enormous suffering of people caused by unsafe foods in Bangladesh, the government should not be excused or allowed to avoid its responsibility to protect its people from such a serious harm caused by the adulterated foodstuffs that are available to consumers in general. This is because the negative contribution of 'legal and regulatory failures ${ }^{46}$ to combat these human sufferings should be given due emphasis in any quest for a durable remedy against this evil. The following discussion focuses on the national and international recognition of the RLRF as a fundamental human right.

\section{The Right to Life and Right to Food}

Both right to life and right to food are regarded as fundamental human rights. All human rights are mutually interdependent, interconnected and inseparable; so the violation of the

\footnotetext{
${ }^{45}$ Rahman, Hoque and Talukder, above n 28, 45.

${ }^{46}$ The discussion of the weaknesses in the existing legal and regulatory regime falls beyond the scope of this article and they will be critically analysed in a separate study.
} 
right to safe food may harm the enjoyment of other human rights. ${ }^{47}$ As a matter of fact, the right to safe food can be a part of different rights, such as the right to health, the right to a certain living standard, right to safety and so on. Girela spells out that food safety is a concern for all such as consumers, the food industry and public administration, and that this fundamental right is clearly derived from other fundamental rights, eg, the right to life, human dignity, the right to protection of health and the right of consumers to legal protection. ${ }^{48}$ Narula considers this right from a different perspective and explains that, if there is a failure of the concerned authority to disclose information about food nutrition, production, and safety, it may be a direct violation of the right to information articulated in art 19 of the International Covenant on Civil and Political Rights 1966 (ICCPR). ${ }^{49}$ As explained by the Office of the High Commissioner for Human Rights (OHCHR) of the United Nations, the violation of the right to food may also involve (may affect and/or be affected by) a violation of the right to water, the right to adequate housing, the right to education, the right to work and to social security, the freedom of association, the right to take part in public affairs, freedom from the worst forms of child labour, freedom from torture, cruel, inhuman or degrading treatment, and so forth. ${ }^{50}$ However, the right to safe food in the present study will be discussed mainly as a part of the RLRF which has been declared as a basic human right in various international human rights instruments as discussed below.

\section{General Concept of the Right to Life}

\footnotetext{
${ }^{47}$ Office of the High Commissioner for Human Rights (OHCHR), 'The Right to Adequate Food: Fact Sheet No 34' (United Nations Human Rights, 2010) 5.

${ }^{48}$ Miguel Angel Recuerda Girela, 'Food Safety: Science, Politics and the Law' (2006)1 European Food and Feed Law Review 33, 36. See also Philip Alston, 'International Law and the Human Rights to Food' in K Tomasevski and P Alston (eds), The Right to Food (Martinus Nijhoff Publishers, 1984) 9, 10. Alston remarked '... enjoyment of the right to food is intimately linked to the enjoyment of a whole range of other human rights including the rights to health, education, and to work, ....'

49 Smita Narula, 'The Right to Food: Holding Global Actors Accountable under International Law' (2006) 44 Columbia Journal of Transnational Law 691, 733[1].

${ }^{50}$ For details see generally, OHCHR, above $n$ 47, 5-6. This document has explained the links between the right to food and other human rights.
} 
Someone can be deprived of life in two ways - by action or by omission of another. An action, such as, execution, disappearance, torture resulting in murder can end a human life; whereas an omission or deprivation such as starvation or failure to receive basic health facilities and medical care can cause the termination of a life. ${ }^{51}$ Traditionally, the abovementioned 'action' is regarded as a violation of the right to life; however, in this narrow view, state's tolerance of malnutrition of its subjects would not be treated equally as an action causing death. ${ }^{52}$ Similarly, it is said that the right to life cannot be reasonably interpreted as right to 'guarantee any person against death from famine or cold or lack of medical attention'. 53

But the concept of state responsibility has changed overtime, and it is no longer the case that the deprivation of life by allowing supply of poisonous foods to the people has to be tolerated except in unavoidable circumstances. Menghistu argued that an interpretation of the right to life that would regard a state's tolerance of malnutrition and failure to reduce infant mortality as outside, and deliberate withholding of food from a prisoner or infants as within, the purview of the inherent right to life as guaranteed in art 6 of the ICCPR ${ }^{54}$ seems to be overly restrictive $^{55}$ According to Menghistu, the definition is manifestly inadequate and should be changed to address the situation affecting the lives of countless people in the world today. ${ }^{56}$ It is gratifying to see that the United Nations Human Rights Committee (UNHRC) appears to agree with this view and it now requires member states to be proactive to ensure the right to

\footnotetext{
${ }^{51}$ F Menghistu, 'The Satisfaction of Survival Requirements' in B G Ramcharan (ed), The Right to Life in International Law (Martinus Nijhoff Publishers, 1985) 63, 63.

${ }^{52}$ Yoram Denstein, 'The Right To life, Physical integrity and Liberty' in Louis Henkin (ed), The International Bill of Rights: The Covenant on Civil and Political Rights (Columbia University Press, New York, 1981) 115.

${ }^{53}$ Nehemiah Robinson, The Universal Declaration of Human Rights: Its Origin, Significance and Interpretation (Institute of Jewish Affairs, World Jewish Congress $2^{\text {nd }}$ ed, 1958) 106; Alston, above n 48, 25.

${ }^{54}$ Article 6(1) of the International Covenant on Civil and Political Rights (ICCPR) declares, 'every human being has the inherent right to life. This right shall be protected by law. No one shall be arbitrarily deprived of his life'.

${ }^{55}$ Menghistu, above n 51, 64.

${ }^{56}$ Ibid.
} 
life including measures to reduce infant mortality. ${ }^{57}$ Menghistu's view can be regarded as representative of this broader and contemporary view of the right to life. It is a relatively recent idea which expands the definition of right to life to an economic and social context, a 'right to live', as it is sometimes called. ${ }^{58}$ The consumption of safe foods does contribute to having a healthy life and constitutes a part of the satisfaction of life. ${ }^{59}$ To the contrary, unsafe foods may end a life suddenly or slowly, directly or indirectly. It is thus obvious that the right to safe food is inalienably attached to the right to life, which makes the issue of unsafe food a valid concern for the protection of human life.

\section{General Concept of the Right to Food}

The right to food is an important one amongst all of the economic, social and cultural rights as food is essential for a human life. ${ }^{60}$ In Gorovitz's words:

$[\mathrm{N}]$ o right has meaning or value once starvation strikes. It is an ultimate deprivation of rights, for without food, life ends, and rights are of value only for living .... Moreover, without adequate nutrition, the value of a right is greatly diminished.... Malnutrition curtails growth, constrains mental and physical development, and limits the possibilities of action. ${ }^{61}$

So, the anxiety to eat food every day has been expressed repeatedly in many ways in the Christian prayer such as 'give us this day our daily bread', 62 and so also by the people of many other religions. In reality, right to food is central to all other rights in that other rights are needed for living with dignity as a human being and a lack of food or the consumption of unsafe food can cause the end of life.

\footnotetext{
${ }^{57}$ Menghistu, above n 51, 66, where the author cites UN Doc. CCPR/C/SR.222 para 59 (1980).

${ }^{58}$ B G Ramcharan, 'The Concept and Dimensions of the Right to Life' in B G Ramcharan (ed), The Right to Life in International Law (Martinus Nijhoff Publishers, 1985) 1, 6; William A Schabas, The Abolition of the Death Penalty in International Law (Cambridge University Press, $3^{\text {rd }}$ ed, 2002) 9[1].

${ }^{59}$ For details, see generally David Felce and Jonathan Perry, 'Quality of Life: Its Definition and Measurement' (1995) 16(1) Research in Developmental Disabilities 51, 51.

${ }^{60}$ Karen Kong, 'The Right to Food for All: A Right-based Approach to Hunger and Social Inequality' (2009) 32 Suffolk Transnational Law Review 525, 560.

${ }^{61}$ S Gorovitz, 'Bigotry, Loyalty, and Malnutrition' in Peter G Brown and Henry Shue (eds), Food Policy: The Responsibility of the United States in the Life and Death Choices (Free Press, Macmillan, New York, 1977) 129, 131-2; Alston, above n 48, 19 [3].

${ }^{62}$ Pierre Spitz, 'The Right to Food in Historical Perspective' (1985) 10(4) Food Policy 306, 306.
} 
It is true that food security is the central concern related to the right to food. But the modern concept of the definition of the right to food has been broadened to incorporate food safety to ensure the active life and sound health of human beings. ${ }^{63}$ This does not undermine the significance of food security in any way. Rather it highlights the importance of food purity believing in that a person can survive for a long time having a meal once a day as long as the food is free from contamination, but the same person may fall sick or even die from consumption of impure foodstuffs regardless of their quantity or frequency of having them.

Having regard to food as the basic need of human beings, the right to food has been recognised as a universal human right since 1948 through its incorporation in the Universal Declaration of Human Rights 1948 (UDHR). ${ }^{64}$ Specifically regarding the RLRF, Renzaho asserts that the UDHR accepted and established fundamental rights for every human and these rights include the right to an adequate standard of life including rights to food ... the right to life'. ${ }^{65}$ Subsequent to the UDHR, the recognition of the RLRF has been reinforced by inserting the right into a variety of instruments. ${ }^{66}$ It can be said that, the right to food has now achieved the status of jus cognens following its recognition in many international human rights instruments as evident from the following discussion. ${ }^{67}$

\section{E. Recognition of the Right to Life and Right to Food under International Human}

\section{Rights Instruments}

A significant amount of literature on international human rights instruments (both binding and non-binding) has mentioned the RLRF as a fundamental human right though the right to

\footnotetext{
${ }^{63}$ Food and Agricultural Organization, Trade and Food Security: Conceptualizing the Linkages (2003) 27 <ftp://ftp.fao.org/docrep/fao/005/y4671e/y4671e00.pdf >.

${ }^{64}$ United Nations Universal Declaration of Human Rights 1948 art 25.

65 Renzaho, Andre M N, 'Human Right to Food Security in Refugee Settings: Rhetoric versus Reality' (2002) 8(1) Australian Journal of Human Rights 43, 45.

${ }^{66}$ Alston, above n 48, 9.

67 See Anthony Paul Kearns, 'The Right to Food Exists via Customary International Law' (1998) 22 Suffolk Transnational Law Review 223, 255-6; Ed Morgan, 'Fear and Loathing in Jus Cogens: A Journey to the Heart of International Law' (2007-2008) 63(1) Canadian International Journal 101, 103; Narula, above n 49, 782 [1].
} 
safe food is not directly stated as a right. However, it can be plausibly argued that an offering of unsafe or poisonous foodstuffs to people indirectly denies their RLRF.

Article 25(1) of the UDHR provides that 'everyone has the right to a standard living adequate for the health and well-being of himself [or herself] and his [or her] family, including food ...', thus it establishes a baseline standard of living and access to adequate food as human rights. ${ }^{68}$ The non-binding provision of the UDHR was later reflected in the ICCPR and in the International Covenant on Economic, Social and Cultural Rights 1966 (ICESCR). ${ }^{69}$ Unlike the UDHR, these two covenants being ICCPR and ICESCR are binding on their state parties. Article 1(2) of both covenants recognises that no one can be deprived of their own means of subsistence. ${ }^{70}$ Article $6(1)$ of the ICCPR articulates the inherent right to life of every human being. So, legally, philosophically and physiologically - the right to food can be considered as a component of the right to life. ${ }^{71}$

The ICESCR is the most important document from a perspective of food. ${ }^{72}$ State parties under art 11 of the ICESCR affirm 'the right of everyone to an adequate standard of living for himself [or her] and his [or her] family, including adequate food....' Later this article was clarified by providing a precise meaning of the adequate food which implies, 'the availability of food in a quantity and quality sufficient to satisfy the dietary needs of individuals, free from adverse substances, and acceptable within a given culture'. ${ }^{73}$ Some commentators

\footnotetext{
68 'Everyone has the right to a standard of living adequate for the health and well-being of himself and of his family, including food, clothing, housing and medical care and necessary social services, and the right to security in the event of unemployment, sickness, disability, widowhood, old age or other lack of livelihood in circumstances beyond his control’: UDHR 1948 art 25(1).

${ }^{69}$ Both the ICCPR and the ICESCR were opened for signature in 1966 and came into effect a decade later.

${ }^{70}$ Office of High Commissioner for Human Rights (OHCHR), Special Rapporteur on the Right to Food: International Standards (2007) <http://www2.ohchr.org/english/issues/food/standards.htm>. Article 1.2 of both the ICCPR and the ICESCR states that, 'All peoples may, for their own ends, freely dispose of their natural wealth and resources. ... In no case may a people be deprived of its own means of subsistence.'

${ }^{71}$ See generally Alston, above n 48, 24.

72 Bernd M J van der Meulen, 'The System of Food Law in the European Union' (2009) 15 Deakin Law Review 305, 312.

73 Committee on Economic, Social and Cultural Rights (CESCR), Substantive Issues arising in the Implementation of the International Covenant on Economic, Social and Cultural Rights: General Comment 12 -
} 
suggest that the right to food under the ICESCR also means that everyone should have sustainable access to 'adequate quality foods'. ${ }^{74}$ However, the term 'adequate food' as contained in various instruments, such as the UDHR, the ICCPR and other international human rights documents, has been clarified by the OHCHR. The OHCHR document in providing this clarification mentions that 'adequacy' refers to the food that must satisfy 'dietary needs' taking into account to the age, living conditions, health, occupation, and sex, etc of individuals. ${ }^{75}$ This UN document further provides as an example that:

If children's food does not contain the nutrients necessary for their physical and mental development, it is not adequate. Food that is energy-dense and low-nutrient, which can contribute to obesity and other illnesses, could be another example of inadequate food. Food should be safe for human consumption and free from adverse substances, such as contaminants from industrial or agricultural processes, including residues from pesticides, hormones or veterinary drugs. ${ }^{76}$

Article 27 of the UN Convention on the Rights of the Child 1989 (CRC) declares that every child has the right to 'a standard of living adequate for the child’s physical, mental, spiritual, moral and social development'. ${ }^{77}$ While art 27(2) of the CRC recognises that parents and others responsible for a child have the prime responsibility to secure 'the conditions of living necessary for the child's development', it nevertheless lays the responsibility on the state parties for facilitating the ability of those parents and caregivers to supply that adequate standard of living. In times of need, state responsibility under art 27(3) includes to provide 'material assistance and support programs, particularly with relation to nutrition ${ }^{78}$... [emphasis added]' to the parents. The right to food (adequate nutritious food and clean drinking water) has also been incorporated in art 24(2) (c) and (e) of the CRC in the context

The Right to Adequate Food (Art. 11) CESCR, 20 ${ }^{\text {th }}$ sess, UN Doc E/C.12/1999/5 (12 May 1999) [8]. See also Asbjørn Eide, The Human Right to Adequate Food and Freedom from Hunger (1998) $<$ http://www.fao.org/docrep/w9990e/w9990e03.htm>.

${ }^{74}$ Narula, above n 49, 694.

${ }^{75}$ OHCHR, above n 47, 3.

${ }^{76}$ Ibid.

${ }^{77}$ Convention on the Rights of the Child 1989 (entered into force 2 September 1990). See also Food Justice, Convention on the Rights of the Child 1989 Articles 24, 27, 32 <http://www.foodjustice.net/internationalstandards/convention-on-the-rights-of-the-child>.

${ }^{78}$ The term 'nutrition' has been emphasised here in a sense that an adulterated foodstuff is generally more poisonous than nutritious. Its nutritious value is damaged by contamination. 
of a child's right to health. Asbjorn comments that 'the right to an adequate standard of living sums up the underlying concern of all economic and social rights' ${ }^{79}$ This right embraces the right to adequate food, that is, food which meets the nutritional needs of the people (in terms of quantity and quality, for example necessary micronutrients), is safe to consume, of good quality and free from all toxic elements and contaminants, and culturally acceptable. ${ }^{80}$

Article 12(2) of the Convention on the Elimination of All Forms of Discrimination against Women 1979 (CEDAW) specifically recognises that every woman has the right to adequate nutrition during pregnancy and lactation. ${ }^{81}$ Consumption of impure foodstuffs during pregnancy may naturally harm not only the mother's health and mind, but also the health and life of her unborn baby. The impairment of the innocent offspring can go to any extent to affect the family as a whole.

Article 8(1) of the Declaration on the Right to Development $1986,{ }^{82}$ notes that state parties are responsible for nationally undertaking all necessary steps for the realisation of the right to development and for this it shall ensure equal opportunity for all in relation to access to different basic resources, including food. ${ }^{83}$ Although this instrument is non-binding, it may (like other Declarations) be viewed as aspirations of, and guidelines for, the nations and therefore they have a persuasive value.

\footnotetext{
${ }^{79}$ Eide, above $n 73$.

${ }^{80}$ Ibid. It should be noted that some persons will starve rather than break religious or cultural taboos.

${ }^{81}$ Convention on the Elimination of All Forms of Discrimination against Women 1979 (entered into force 3 September 1981).

${ }_{82}$ 'States should undertake, at the national level, all necessary measures for the realization of the right to development and shall ensure, inter alia, equality of opportunity for all in their access to basic resources, education, health services, food, housing, employment and the fair distribution of income. Effective measures should be undertaken to ensure that women have an active role in the development process. Appropriate economic and social reforms should be carried out with a view to eradicating all social injustices': United Nations Declaration on the Right to Development 1986, art 8(1).

${ }^{83}$ OHCHR, above n 70.
} 
State parties in art 1of the World Declaration on Nutrition 1992 recognise that access to the nutritionally adequate and safe food is a right of each individual. ${ }^{84}$ Again while non-binding, such a document almost inevitably must bring to bear a degree of moral persuasion for signatories. Such a persuasive effect is evident in the resolution of the world leaders in 1996. The World Food Summit 1996 organised by the Food and Agriculture Organisation (FAO) in Rome reaffirmed that everyone has a right to access safe and nutritious food, ${ }^{85}$ and the Rome Declaration on World Food Security 1996, an outcome of the World Food Summit, emphasised the right to safe food once again. ${ }^{86}$

Agreements of the international community play a pivotal role in the development of international human rights law. The principles and provisions of international law are founded upon the Latin principle pacta sunt servanda (agreement must be kept). When state parties give consent to a certain accord of the international community, it becomes binding on the consenting states by virtue of their agreement. The United Nations General Assembly (UNGA) resolutions are of great importance for international relations as they are drafted and adopted with the participation of many countries. There are various resolutions of the United Nations which have embraced access to safe food as a right of all people. Resolution 51/171 on Food and Sustainable Agricultural Development adopted by the UNGA in 2001 reaffirmed the 'right of everyone to have access to safe and nutritious food consistent with the right to adequate food and the fundamental right of everyone to be free from hunger' ${ }^{87}$ This Resolution urged member states to implement the Plan of Action issued at the World Food Summit $1996 .^{88}$ Similarly, Resolution 57/226 on the Right to Food adopted in 2003 by the UNGA also states that everyone has the right to access safe and nutritious food, consistent

\footnotetext{
${ }^{84}$ OHCHR, above $\mathrm{n} 70$.

${ }^{85}$ Rome Declaration on World Food Security (World Food Summit, 13 November 1996) WSFS 2009/2. Its text can be viewed at FAO <http://www.fao.org/docrep/003/w3613e/w3613e00.HTM>.

${ }^{86}$ Ibid; Narula, above n 49, 788[2].

${ }^{87}$ United Nations, GA Resolution $51 / 171$ on food and sustainable agricultural development A/RES/51/71 $86^{\text {th }}$ plen mtg (16 December 1996). See also OHCHR, above n 70.

${ }^{88}$ Ibid.
} 
with the right to adequate food and the right to be free from hunger as these rights are needed for the development and maintenance of physical and mental capacities of all human beings. ${ }^{89}$

The preceding discussion demonstrates the international recognition and importance of the RLRF. Bangladesh, as a member of the United Nations and party to the most of the international instruments mentioned above has assumed obligation to ensure food safety in the country. Bangladesh is a state party to major international human rights instruments, such as the ICCPR (ratified on 6 September 2000), the ICESCR (ratified 5 October 1998), the CRC (ratified on 3 August 1990), and the CEDAW (ratified on 6 November 1984), etc. All are very important instruments in regard to the RLRF. As a member state to these treaties, the Government of Bangladesh has the obligation to promote and protect human rights for all. In regard to the realisation of the right to safe food, Ziegler stressed that, the commitment of Bangladesh to human rights should be taken into consideration in any study of the right to food in the country. ${ }^{90}$ He says:

The Government of Bangladesh is obligated to respect, protect and fulfil all human rights, including the right to food. Specific violations of these obligations should be documented and treated as human rights violations, although few organizations in Bangladesh are yet working to monitor and document violations of the right to food. ${ }^{91}$

\footnotetext{
${ }^{89}$ Right to Food, GA Res 57/226, UN.GAOR, $57^{\text {th }}$ Sess, $77^{\text {th }}$ plen mtg, Supp No 49, UN Doc A/RES/57/226 (26 February 2003) 2; See Narula, above n 49, 785[1].

In addition to the above mentioned international human rights instruments and the Resolutions of the United Nations, there are other human rights instruments which have also incorporated the RLRF. Prominent other binding instruments that include the RLRF are: the United Nations Convention Relating to the Status of Refugees 1951(Refugee Convention), art 20), and the Convention on the Rights of Persons with Disabilities 2006 (CRPD) (art 25 and 28).

Other important non-binding instruments that have incorporated the RLRF are: the Universal Declaration on the Eradication of Hunger and Malnutrition 1974 (art (b), 1, 2), the World Declaration on the Survival, Protection and Development of Children 1990 (art 10), the Vienna Declaration and Programme of Action 1993 (art 31), the Rome Declaration on World Food Security 1996, the Declaration of the World Food Summit 2002 (art 14), the Declaration on the Rights of Indigenous Peoples 2007 (art 7(1)).

${ }^{90}$ Jean Ziegler, Report of the Special Rapporteur, Right to Food: Mission to Bangladesh, $16^{\text {th }}$ sess, UN Doc E/CN.4/2004/10/Add.1 (29 October 2003) 9 [18].

${ }^{91}$ Ibid 17[42].
} 
In fact, the ultimate obligation to respect, protect and fulfil human rights lies with the government which cannot delegate this responsibility. ${ }^{92}$ Every government has the primary obligation to respect, protect, promote and fulfil human rights. ${ }^{93}$ This obligation of Bangladesh is premised on the following grounds.

Bangladesh is a party to major international instruments, therefore, it has the obligation to protect, promote and fulfil human rights contained in those instruments. As alluded to earlier, the RLRF is embodied in those instruments. Further, the state has to ensure that no institutions of the state undermine the people's right to safe food and it should regularly review and update the rules and regulations to ensure people's enjoyment of the RLRF. ${ }^{94}$

More specifically, art 2 of the ICCPR obligates its member states to 'adopt such legislative or other measures as may be necessary to give effect to the rights recognised by the Covenant'. This means that Bangladesh has the obligation since it ratification in 2000 to immediately take steps to protect the RLRF and adopt the up-to-date regulations for the protection of the right to safe food. ${ }^{95}$ The ICESCR imposes similar obligation on its members and Bangladesh assumed its obligation since the ratification of the ICESCR in 1998. Additionally, the United Nations Committee on Economic, Social and Cultural Rights emphasises that every state party has the responsibility to ensure the satisfaction of each right at least for the minimum level. ${ }^{96}$ Further, the United Nations resolutely states that:

\footnotetext{
${ }^{92}$ United Nations, General Assembly, Human Rights Council-Agenda Item 3, $15^{\text {th }}$ sess, A/HRC/15/55, 'Joint report of the independent expert on the question of human rights and extreme poverty, Magdalena Sepúlveda Cardona, and the independent expert on the issue of human rights obligations related to access to safe drinking water and sanitation, Catarina de Albuquerque - Mission to Bangladesh' (3-10 December 2009) 13 $<$ http://daccess-dds-ny.un.org/doc/UNDOC/GEN/G10/154/51/PDF/G1015451.pdf?OpenElement>.

${ }^{93}$ OHCHR, above n 47, 17.

${ }^{94}$ Ibid 18.

95 See generally A H Monjurul Kabir, Autonomy of Public Broadcasting: From 'Absolute Control' to 'Controlled Autonomy' (2010) Bangla Rights.net <http://www.banglarights.net/HTML/incidence-5.htm>

${ }^{96}$ Committee on Economic, Social and Cultural Rights (CESCR), Substantive Issues arising in the Implementation of the International Covenant on Economic, Social and Cultural Rights: General Comment No. 14 (2000) The right to the highest attainable standard of health (article 12 of the International Covenant on Economic, Social and Cultural Rights) (22nd sess, 2000) UN Doc E/C.12/200/4 (11 August 2000) [2], [43]; see
} 
The obligation to protect also includes ensuring that food put on the market is safe and nutritious. States must therefore establish and enforce food quality and safety standards, and ensure fair and equal market practices. Furthermore, States should take the legislative and other measures needed to protect people, especially children, from advertising and promotions of unhealthy food so as to support the efforts of parents and health professionals to encourage healthier patterns of eating and physical exercise. ${ }^{97}$

As revealed from the above discussions, Bangladesh has a categorical obligation to ensure food safety in the country under its international commitments. The OHCHR thus reinforces this obligation by stating that Bangladesh must be proactive in strengthening access to an adequate standard of life and the right to access of safe food. ${ }^{98}$

To wrap up, it is internationally recognised that access to safe food is a right, and not merely a privilege of a human being regardless of his or her residence and economic solvency. Bangladesh has clearly assumed an obligation to ensure this right for its residents. So, depriving the millions of people of safe food in the country is truly a denial of their legitimate right, which, in effect, amounts to deprivation of their lives as evident in the Table provided earlier.

Further, in addition to its international responsibility, Bangladesh has the constitutional obligation to ensure food safety for its people as discussed below.

\section{F. Recognition of the RLRF under the Constitution of Bangladesh}

The RLRF is well embedded in the Constitution. It is enshrined in different articles of the

Constitution which is the supreme law of the land. ${ }^{99}$ Hence, the right to life is a fundamental right of the people as guaranteed by the Constitution. Article 32 provides that 'no person shall be deprived of life or personal liberty save in accordance with law'. Further, art 31 of the

\footnotetext{
also Redwanur M Rahman, 'Human rights, Health and the State in Bangladesh' (2006) 6(1) BMC International Health and Human Rights <http://ey9ff7jb6l.scholar.serialssolutions.com/?sid=google\&auinit=RM\&aulast=Rahman\&atitle=Human+rights ,+health+and+the+state+in+Bangladesh\&id=pmid:16611360> .

${ }_{97}^{9}$ OHCHR, above n 47, 18.

${ }^{98}$ Ibid.

${ }^{99}$ Constitution of the People's Republic of Bangladesh 1972 art 7.
} 
Constitution states that every person in Bangladesh has an inalienable right to enjoy the protection of the law as well as to be treated in accordance with law. In particular, any action detrimental to the life, liberty, body, reputation or property of any person shall not be taken, except in accordance with law. ${ }^{100}$ The High Court Division of the Supreme Court of Bangladesh held in Gias Uddin v Dhaka Municiple Corporation and Others that the protection of life under art 31 of the Constitution means that one's life cannot be endangered by any action which is illegal. ${ }^{101}$ Consistently, the same Supreme Court pronounced in Professor Nurul Islam v Government of Bangladesh that the right to life under art 31 of the Constitution means the right to have a sound mind and health. ${ }^{102}$ Quite logically, sound health essentially requires safe food. Thus arguably, these two articles, arts 32 and 31, demonstrate the existence of the RLRF in the Constitution of the country. In addition, it can be relevantly mentioned here that food adulteration is categorically prohibited by penal as well as regulatory laws in Bangladesh, which has been critically analysed elsewhere. ${ }^{103}$

Furthermore, art 18(1) of the Constitution touches upon the RLRF. Unlike the other two articles as mentioned above, art 18(1) does not proffer a fundamental right; rather it contains a state duty as a fundamental state policy, which also provides an indication of the presence of the right to food in the Constitution. Article 18(1) of the Constitution reads as follows:

The State shall regard the raising of the level of nutrition and the improvement of public health as moving its primary duties, and in particular shall adopt effective measures to prevent the consumption, except for medical purposes or for such other purposes as may be prescribed by law, of alcoholic and other intoxicating drinks and drugs which are injurious to health.

Article 18(1) has been relevantly applied and interpreted in a recent verdict of the Supreme Court of Bangladesh with respect to the issue of food safety in Bangladesh. The petitioner in

\footnotetext{
${ }^{100}$ Ibid art 31.

101 (1997) 17 BLD (HCD) 577.

102 (2000) 20 BLD (HCD) 341.

103 For example, ss 272 and 273 of the Penal Code 1860 (Bangladesh), s 25C of the Special Powers Act 1974 (Bangladesh), ss 6, 6A and 7 of the Pure Food Ordinance 1959 (Bangladesh) and s 41 of the Consumer Rights Protection Act 2009 (Bangladesh) [author's trans] clearly prohibit food adulteration in Bangladesh.
} 
Farooque $v$ Government of Bangladesh, ${ }^{104}$ (a 1996 case involving the importation of allegedly radioactively contaminated milk powder), claimed an infringement of the right to life guaranteed under art 32 and protected under art 31of the Constitution. In support of his claim under arts 31 and 32, the petitioner cited art 18(1) on the ground of public health. Recognising the relevance of art 18(1) and the infringement of constitutional right to the RLRF by adulterated foods in Bangladesh, Kazi Ebadul Hoque $\mathrm{J}$ held in this public interest litigation that:

[T] hough article 18 cannot be enforced by the Court, it can be ... [consulted for] interpreting the meaning of the right to life under Articles 31 and 32. A man [or woman] has a natural right to the enjoyment of healthy life and longevity up to normal expectation of life in an ordinary human being. Enjoyment of a healthy life and normal expectation of longevity is threatened by disease, natural calamities and human actions. When a person is grievously hurt or injured by another, his [or her] life and longevity are threatened. Similarly, when a man [or woman] consumes food, drink, etc, injurious to health, he suffers ailments and his [or her] life and normal expectation of longevity are threatened. The natural right of man [or woman] to live free from all the man made hazards of life has been guaranteed under the aforesaid Articles 31 and 32 subject to the law of the land [emphasis added]. ${ }^{105}$

Thus the highest court of the country clearly has established that food adulteration and the supply of contaminated foodstuffs for human consumption contravene a fundamental human right guaranteed by the Constitution. Also, it is repugnant to a state duty under a fundamental state policy.

Finally, food safety is being emphasised by most of the governments around the world. In developed countries, the most governments are establishing a separate food safety mechanism, ${ }^{106}$ and creating a separate authority to look after particularly the food safety issues. For example, the US Food and Drug Administration (USFDA) in the US, the Food Standard Agency (FSA) in the UK and the New South Wales Food Authority (NSWFA) in NSW, Australia look after the entire food safety regulatory framework in their respective jurisdictions. Although Bangladesh is a third world country, food safety is an issue which is

\footnotetext{
${ }^{104}$ Farooque v Government of Bangladesh (1996) 48 DLR 438.

${ }^{105}$ Ibid.

106 David A Hennessy, Jutta Roosen and Helen H Jensen, 'Systemic Failure in the Provision of Safe Food' (2003) 28 Food Policy 77, 93[2].
} 
equally crucial for every human being regardless of their national identify or financial ability. If a question of preference amongst the poor and the rich with respect to safe food arises for any reason whatsoever, the former who are unable to afford to pay for proper medical treatment, should get priority over the latter. This is so because, every life is a life which has the inherent right to live until its natural death occurs. The Government of Bangladesh has assumed obligation to ensure food safety and protect the relevant fundamental and human rights. Hence, the persons involved in food adulteration in Bangladesh have been grossly violating RLRF for decades with impunity. Likewise, the government also is in breach of its constitutional and international legal obligations by its failure to combat the rampant food adulteration in the country. These violations are not victimless. Hundreds of people are getting killed - some of them slowly and some others instantly. Besides, the breaches are affecting the national economy by increasing healthcare costs and decreasing productivity. Such a miserable condition of human lives and their fundamental rights cannot and should not be ignored or tolerated any longer.

\section{G. Consumer Preference and Concern for Their Awareness}

A part of the overall problem with food safety regulation in Bangladesh is made up of consumer preference to buy certain foodstuffs simply because of their financial constraint, buying trend or lack of awareness of potential harms that may be caused by their preferred products. So, an effective solution to the violation the RLRF may entail boosting awareness of consumers about the harmful effects of adulterated foodstuffs.

The price of foods is one of the reasons of the production and consumption of the unsafe food in Bangladesh. Food is a goods like any other consumer products, and its price is determined to a certain extent by the market forces of demand and supply. Some consumers cannot afford to pay particular food products in any country beyond a specific price, and ultimately this 
inability may cause the demonstrations and riots for subsidy or rationing in some way so as to guarantee access to the food. ${ }^{107}$ Adulterated foods are sometimes cheaper (eg, fast-foods fried in palm oil or even sometimes incredibly in used engine oil) than others. But most of the time they have to pay additionally for the poisonous chemicals used by the delinquent sellers, for example, fish or fruits mixed with formalin or other harmful chemicals. Sellers as business people will naturally recover the full costs from buyers. Sometimes consumers ignore the risks involved, some other times they are unaware of adulteration. A group of researchers in Bangladesh recently surveyed 110 consumers, 25 sellers, 7 doctors and 7 pharmacists in the capital city of Dhaka to examine the reasons for consumers feeling 'compelled to consume chemically treated foods'. ${ }^{108}$ The authors found that food producers always sought to achieve greater profit by using lower price inputs and this led to producers in developing countries using cheaper, often hazardous and industrial chemicals in food. ${ }^{109}$ They found that 37 per cent of the consumers surveyed buy adulterated foods because they are cheaper and commonly available than unadulterated ones; while 15.5 per cent of consumers buy chemically treated foods because they look nice and therefore are more attractive to them. ${ }^{110}$ So, it is obvious that adulterated foods are likely to be priced at the lower end of the market which leads the consumers buy it. But this cannot be allowed to be an excuse to manufacture, and then allow those people who cannot pay much for the safe food to consume unsafe food. Consumers must be prevented from consuming adulterated food as far as practicable. Safe food should be made available and affordable equally for everyone irrespective of the

\footnotetext{
${ }^{107}$ As has happened in recent years in many countries around the world, including Bangladesh, Indonesia, Thailand etc. See for details, Mindi Schneider, We are Hungry! A Summary Report of Food Riots, Government Responses, and States of Democracy in 2008 (2010), Stuffed and Starved $<$ http://stuffedandstarved.org/drupal/files/We\%20are\%20Hungry\%20\%20A\%20Summary\%20Report\%20of\%20Food\%20Riots,\%20Government\%20Responses,\%20andStates\%20of \%20Democracy\%20in\%202008.pdf>.

${ }^{108}$ Md Motaher Hossain, Visa Heinonen and K M Zahidul Islam, 'Consumption of Foods and Foodstuffs Processed with Hazardous Chemicals: A Case Study of Bangladesh' (2008) 32(6) International Journal of Consumer Studies 588, 588.

${ }^{109}$ Ibid.

${ }^{110}$ Ibid 591.
} 
economic capacity of the consumers under any circumstance. Offering someone adulterated food, whether adulterated by chemicals, or by un-nutritious or less nutritious 'fillers', or by bacteria or moulds, is directly offering to make the consumers ill, and indirectly to shorten or even end their lives.

Despite the trend of preference of lower price products by consumers, the non-availability of unadulterated food items in the marketplace is also a big concern regarding food safety issues in the country. If there are insufficient numbers of food manufacturers for a particular food item, and consequently supply of that food product is low, consumers are bound to buy a food that may be adulterated as it gives the appearance of there being more of that particular foodstuff. As mentioned above, formalin treated fish is generally sold at quite a high price, and the chemical is also reportedly used in milk and on vegetables and fruits. ${ }^{111}$ Consumers have to buy those tainted items in the absence of their non-adulterated equivalents in the markets located within their reach. Consumers in most of the developing countries, however, place greater emphasis on the satisfaction of their immediate physiological needs. Hence, consumers in such market conditions accept whatever is offered to them; they have very little choice in the marketplace, so very little voice over what is produced and how it is produced. $^{112}$

Another aspect of the problem of food safety is a serious lack of consumer information and education. The provision of information to consumers on food products whether they are adulterated or not is a very important concern in relation to the food safety issue in Bangladesh. If someone does not know about any particular food product, that means he or

\footnotetext{
${ }^{111}$ Kazi S M Khasrul Alam Quddusi, 'Challenges of Governance in Bangladesh' (2008) 38(2) Social Change 274, $281<$ http://sch.sagepub.com/content/38/2/274.full.pdf>. The author notes 'we are buying death or deadly diseases and that too, at a very high price. Recently, 6.5 tonnes of formalin-treated fish have been recovered in only one raid in Dhaka city'.

112 A C Reddy and D P Campbell, Marketing's Role in Economic Development (Quorum Books, 1994); M Quazi Ali, 'Managerial Views of Consumerism: A Two-country Comparison' (2000) 36(1-2) European Journal of Marketing 36, 38.
} 
she can assume it prima facie as safe and buy it for consumption. Recently a group of researchers investigated whether even urban dwellers are aware of food safety from media coverage in Bangladesh. ${ }^{113}$ They found that urban consumers like to buy processed food and they believe in the food labels regardless of truth in them. ${ }^{114}$ More alarmingly, rural consumers, living in remote areas where there is no electricity or the media coverage, are 'in the dark' regarding food safety issues. Such circumstances put them in a vulnerable position and lead them to consume adulterated foods regularly and almost unknowingly. In Bangladesh, consumer education is at a poor level. Some newspapers do publish some news items about food adulteration, but a large number of people are unaware of the media reports and some of them seldom care about adulteration despite their knowledge of these reports. Currently the literacy rate in Bangladesh is 53 per cent. ${ }^{115}$ So a vast quantity of the country’s large population is unable to read, therefore, are utterly inept to distinguish between 'unsafe' or 'safe' foods, particularly if the product is not visibly affected or lacks a tell-tale odour.

Some of the illiterate people may also think that a food in a nice packet or brightly coloured is good for their health or unadulterated. Sometimes, consumers are always not able to judge the longer-term risk factors, such as a nutritional imbalance in the diet, and food additives or pesticide residues in foodstuffs, even if the information is provided and they can read. For example, coloured sweetmeats are extremely popular in Bangladesh as they look very attractive and tasty. But very few consumers know about the long term effects of the consumption of these artificial textile colours used in such alluring food products. Consumers may not even judge the immediate effects of some particular food. In fact, many of the direct

\footnotetext{
${ }^{113}$ S S M Sadrul Huda, Ahmed Taneem Muzaffar and Jashim Uddin Ahmed, 'An Enquiry into the Perception on Food Quality among Urban People: A Case of Bangladesh' (2009) 3(5) African Journal of Business Management 227, 228.

${ }^{114}$ S S M Sadrul Huda, Ahmed Taneem Muzaffar and Jasim Uddin Ahmed, 'The Perception on Food Quality among Urban People’ (Working Paper No AIUB-BUS-ECON-2008-17, American International University, Bangladesh, 2008), 6[1].

115 'What is the Literacy Rate in Bangladesh, a Country in the Continent of Asia?' <http://countryfacts.findthedata.org/q/136/2395/What-is-the-literacy-rate-in-Bangladesh-a-country-in-the-continent-of-Asia>.
} 
effects may never be apparent, and those that are observable may be confined to the longer term complications. In these situations, consumers who are health conscious generally rely upon the external risk indicators to understand the level of food safety. Mitchell has analysed consumer perceived risk regarding a number of food products and the risk indicators employed in consumer choice processes. Important indicators identified were brand, product information, price, the nature of food packaging, the nature of the food store and the store's ability to handle produce. ${ }^{116}$ But in fact, none of the indicators is either reliable at all or readable to many due to lack of education as alluded to earlier. So, both accurate risk indicators and adequate consumer education are imperative to make the safety regulation a success. ${ }^{117}$

\section{H. Drawbacks in the Legal and Regulatory Regime for Food Safety in Bangladesh}

Although the Constitution explicitly recognises the right to life as a fundamental right and the right to food is an integral part of that right as interpreted by the highest court of the judiciary of Bangladesh, the existing legal and regulatory framework for food safety appears to have scant regard for this right. Admittedly, enforcement is more frustrating than the provisions of law, however, there is not much to be complacent about the legal framework in terms of ensuring food safety in the country. The present legal and regulatory framework falls short of constitutional and international standards in various respects. Some of the shortcomings are discussed below.

i. Setting appropriate food standards should be regarded as the first step in ensuring supply of safe foods to consumers. Several national and international studies reveal that food standards

\footnotetext{
${ }^{116}$ V W Mitchell, 'Consumer Choice of Risky Food Products: The Role of Indicators in Food Choice' (Paper presented at the Consumers and Food Borne Risks: An Interdisciplinary Workshop, University of Reading, UK, May 1992); Spencer Henson and Bruce Traill, 'The Demand for Food Safety : Market Imperfections and the Role of Government' (1993) 18(2) Food Policy 152, 157.

${ }^{117}$ The importance of consumer education and awareness for food safety in Bangladesh has also been stressed in a recent food safety seminar in Bangladesh; see 'Improving Food Safety, Quality and Food Control in Bangladesh: Report - Seminar on Food Safety Challenges in Bangladesh' (Food and Agriculture Organization of the United Nations, June, 2010) 4.
} 
made under the authority of the Bangladesh Standard Testing Institute Ordinance 1985 (BSTIO 1985) do not embody the updated and recent recommendations of the Codex Alimentarius, ${ }^{118}$ which is the international food standards setting authority empowered by the World Health Organisation (WHO) and the United Nations Food and Agriculture Organisation (FAO). While most countries have adopted the updated international standards of Codex $^{119}$ for their food safety regulation, Bangladesh is still lagging behind. Thus the food standards that are supposed to be applied to ensure food safety in Bangladesh fall short of international standards.

The adoption of the safe standards as devised by the international authority and their maintenance in practice are perhaps the most important concerns of food safety that help protect the right to safe food of the public. But Bangladesh has a clear deficiency in such a critical need for compliance with the international standards. In this regard, Henson and Jaffee assert that food safety control systems demonstrate deficiency in many countries due to the 'weaknesses in their legislative frameworks' and their failure to comply with 'international standards and norms ${ }^{\text {120 }}$ Therefore, Bangladesh needs to immediately update its food safety laws embracing the food standards as prescribed in the latest Codex Alimentarius. In addition, Bangladesh should include mandatory food labeling provisions and ensure that the labeling contains the true information about the food attached to it.

ii. Although consumers are the ultimate victims of unsafe foods, they were not entitled to seek compensation from a competent court until recently. Amongst the numerous pieces of

\footnotetext{
${ }^{118}$ United Nations, 'The Common Country Assessment Bangladesh' (September 1999) 54; see Ziegler, above $n$ 90, 11; National Taskforce on Food Safety, above n 40, 4; Deon Mahoney, 'Keynote Paper: Food Safety Challenges in Bangladesh- Protecting the Consumer' (Paper Presented at National Workshop on building a Food Safety Advocacy Network in Bangladesh, 9-10 November 2010) 11; Peter Sousa Hojskov, 'Overview of Food Control System in Bangladesh' (Paper Presented at National Workshop on Building a Food Safety Advocacy Network in Bangladesh, 9-10 November 2010) 2.

119 For details about Codex international standards, see Codex Alimentarius, About Codex (2013) $<$ http://www.codexalimentarius.org/about-codex/en>.

${ }^{120}$ Spencer Henson and Steven Jaffee, 'Understanding Developing Country Strategic Responses to the Enhancement of Food Safety Standards' (2008) 31(4) World Economy 548, 565.
} 
legislation governing the area of food safety as mentioned below, only the Vokta Odhikar Songrokkhon Ain 2009 (Consumer Rights Protection Act 2009, hereinafter CRPA 2009), the latest enactment in this area in the country, contains a provision of civil remedy, while others are solely confined to criminal penalties. Section 66(1) of the CRPA 2009 entitles a consumer to claim compensation or damages. Although they are entitled to claim compensation, the present writers have not found any reported case under s66(1). Other laws are still reliant on exclusively criminal liability depriving consumers from compensation.

Perhaps more frustratingly, the CRPA 2009 does not allow consumers to initiate a criminal proceeding against the wrongdoers as stated in s71(1) of the CRPA 2009. However, a consumer under s71(2) of the CRPA 2009 may lodge a complaint with the Director General of the the Directorate of National Consumer Rights Protection (DG) or to the District Magistrate or to any other person authorised by them to that effect. Section 76 empowers the DG to carry out an investigation into the complaint and impose administrative fine on the person who would be found guilty for the contravention of the CRPA 2009. However, the CRPA 2009 does not mention anything about the consequence if the DG fails to investigate the complaint lodged by an aggrieved consumer. Instead, paradoxically indeed, a consumer may be punished if his/her allegation submitted to the DG is found to be untrue in the investigation. ${ }^{121}$ It should be mentioned that given the practice of political interference and widespread corruptions in public sectors in general, the role of the DG in dealing with such complaints can be vitiated by some 'undue' influence or subjective consideration. Referring to the weaknesses of the CRPA 2009, Professor Mizanur Rahman, the incumbent Chairman of the National Human Rights Commission, expressing his disappointment said that the 'the

${ }^{121}$ The Consumer Rights Protection (Meetings and Proceedings) Rules 2010, rule 12(3). 
CRPA 2009 does not provide consumers with any rights. It is meaningless to knowingly make such a law'.122

Restricting consumer right to prosecute offenders in relation to food safety has been a long tradition in Bangladesh. ${ }^{123}$ Their right is constrained not only by the CRPA 2009, but also some other laws. For example, currently only the designated officials can prosecute a food manufacturer or seller under the Pure Food Ordinance 1959 (PFO 1959) and the BSTIO 1985. Consumers should be given an unqualified right to sue the wrongdoers in both civil and criminal courts and restriction may be imposed at a later stage only if credible evidence of misuse of that right requires to do so. This right is particularly important in Bangladesh mainly because of the passivity of regulators and a common trend of political interference with regulatory matters by successive governments. The right to safe food without a corresponding right to seek remedy against violations of the right seems contrary to the international and constitutional entitlement of consumers to access to safe foods.

iii. There are numerous statutes governing the area of food safety, and different authorities are responsible for the administration and enforcement of those laws. Major pieces of such legislation include: the Penal Code $1860,{ }^{124}$ the Pure Food Ordinance $1959,{ }^{125}$ the Cantonments Pure Food Act 1966, ${ }^{126}$ the Pesticide Ordinance $1971,{ }^{127}$ the Fish and Fish Products (Inspection and Control) Ordinance $1983,{ }^{128}$ the Bangladesh Standards and Testing Institution Ordinance $1985,{ }^{129}$ the Consumer Rights Protection Act $2009^{130}$ and the Mobile

\footnotetext{
${ }^{122}$ Rajib Ahmed, 'Consumer Rights Law - Complainants Themselves Will be Troubled' The Kaler Kanthha, Dhaka (22 January 2010) [author’s translation].

${ }^{123}$ Mizanur Rahman, 'Consumer Protection in Bangladesh: Law and Practice' (1994) 17(3) Journal of Consumer Policy 359-60; see also Zafrin Andaleeb and Abu Noman Mohammad Atahar Ali, 'The Development of Consumer Protection Law in Bangladesh: A Critical Comparative Study' (2009) 2(1) Independent Business Review 131, 133-4.

${ }^{124}$ Administered and enforced under the Ministry of Health and Ministry of Local Government.

${ }^{125}$ Administered and enforced under the Ministry of Health and Ministry of Local Government.

${ }^{126}$ Administered and enforced under the Ministry of Defence.

${ }^{127}$ Administered and enforced under Ministry of Agriculture.

${ }^{128}$ Administered and enforced under the Ministry of Fisheries.

${ }^{129}$ Administered and enforced under the Ministry of Industries.
} 
Court Act $2009^{131}$. Each of these pieces is enforced by separate regulatory authorities as footnoted below, which creates a regulatory overlapping. The multiplicity of both legal provisions as well as regulatory authorities generate confusions amongst the regulators themselves, food manufacturers and consumers about the applicable laws, relevant regulatory authorities and appropriate remedies etc. ${ }^{132}$ Referring to such a situation, the famous Hampton Review in the United Kingdom finds that '62 per cent of small food business proprietors do not understand which food safety regulations are relevant to them'. ${ }^{133}$ Effective enforcement of any right requires precision in definition of wrongs, and specificity in regulation and coherence in enforcement efforts. For example, the food regulation of New South Wales Australia (NSW) is widely acclaimed in home and abroad as one of the most successful regulatory regime. ${ }^{134}$ Unlike the legal and regulatory multiplicity in Bangladesh, NSW has a single enactment titled the Food Act 2003 (NSW) which is concerned with unsafe and harmful foodstuffs in this most populous State of Australia. The responsibility for the administration of this legislation and thereby ensuring food safety is vested mainly in the NSW Food Authority (NSWFA) which is responsible to the Minister for Primary Industries. ${ }^{135}$ This simplicity in NSW helps eliminate the confusions and complexities in relation to food safety regulation that exist in Bangladesh.

\footnotetext{
${ }^{130}$ Administered and enforced under the Ministry of Commerce.

131 Administered and enforced under the Ministry of Public Affairs.

${ }^{132}$ Abu Noman Mohammad Atahar Ali, 'Food Safety and Public Health Issues in Bangladesh: A Regulatory Concern’ (2013) 8(1) European Food and Feed Law Review 31, 36-37.

133 See Philip Hampton, 'Reducing Administrative Burdens: Effective Inspection and Enforcement' (HM Treasury, London, United Kingdom, 2005) 5.

${ }^{134}$ For example, see generally E A Szabo, W R Porter and C L Sahlin, 'Outcome Based Regulations and Innovative Food Processes: An Australian Perspective’ (2008) 9(2) Innovative Food Science \& Emerging Technologies 250; Productivity Commission, Performance Benchmarking of Australian and New Zealand Business Regulation: Food Safety, Research Report (2009) 362; Tania Martin et al, 'A New Era for Food Safety Regulation in Australia' (2003) 14(6) Food Control 429; Karinne Ludlow, 'The Readiness of Australian Food Regulation for the Use of Nanotechnology in Food and Food Packaging’ (2007) 26 University of Tasmania law Review 177, 184-189; Eric Middledorpm, 'Food Act 2003 and Food Regulation 2004: An Overview’ (2004) 4(1) Environmental Health 89, 91; S MacKay, 'Legislative Solutions to Unhealthy Eating and Obesity in Australia' (2011) 125(12) Public Health 896, 898, 900-1.

${ }^{135}$ NSW Government, 'Safer Food, Clearer Choices' (NSW Food Authority, Annual Report 2011-12) 4.
} 
More importantly, there is a serious lack of coordination amongst the diverse regulators, which results in a dearth of enforcement actions against violations. For example, the BSTI deals with the standards of numerous products including foods in the country. But the regulatory authority of BSTI is limited in regard to food standards and it is responsible merely for determining the quality of manufactured packaged food items, not for nonpackaged (but processed) foods, such as, the dried fish (locally called as sutki) ${ }^{136}$ which is due to be regulated under the Ministry of Fisheries (MOF). But there is no instance of regulating this non-packaged processed food by the MOF to the best of the present writers' knowledge. As a result, those items ultimately remain unregulated. Highlighting this problem, Ali pointed out that the lack of coordination of laws and their administration is the main reason for the widespread violations of consumer protection laws in Bangladesh. ${ }^{137}$

iv. 'Justice delayed is justice denied' - is an old proverb which came true to the judiciary of Bangladesh. Logjam of cases has been a serious and chronic problem in the administration of justice in the country. ${ }^{138}$ According to the chief justice of the day, as at 1 January 2012, about 2,132,046 cases had been pending in all courts and tribunals, including the Supreme Court of Bangladesh which is made up of the High Court Division and the Appellate Division. ${ }^{139}$ Currently there are more than 300,000 cases pending before the High Court Division alone, which has only 90 judges, whilst the Appellate Division of 10 judges is inundated with 17,000 cases. ${ }^{140}$ Inordinate delays in the disposal of cases cause denial of justice and discourage the victims of breach of law to file a court case. Perhaps to avoid such a sore reality, the PFO 1959 provides that the judicial enforcement of the food safety regulations should be carried out by Pure Food Courts (PFCs). Section 41 of the PFO 1959 requires the

\footnotetext{
${ }^{136}$ Staff Correspondent, 'BSTI Denies any Role in Quality Control of Non-packet Products', News Network (Dhaka), (online), 20 November $2008<$ http://www.news.org.bd/?p=9773>.

${ }^{137}$ Ali, avove n 25, 113; see also Food Safety Project Team, above n 117.

${ }^{138}$ See M Rafiqul Islam \& S M Solaiman, 'Public Confidence Crisis in the Judiciary and Judicial Accountability in Bangladesh’ (2003) 13 Journal of Judicial Administration 29.

139 'Judiciary Beset with 21 Lakh Pending Cases: CJ' The Daily Star, Dhaka (19 May 2012), Metropolitan.

${ }^{140}$ Ashutosh Sarkar, HC to get 20 New Judges, The Daily Star, Dhaka (20 April 2013).
} 
government to establish a PFC in every district, and metropolitan areas (there are 64 districts and seven city corporations in the country). Accordingly, the Supreme Court of Bangladesh has ordered the government to implement s41 by establishing a PFC in every district, but the order went unheeded. ${ }^{141}$ It is believed that the establishment of such courts itself will serve as a warning to potential wrongdoers about the sincerity of the government to ensure food safety and thereby it will have an inherent deterrence effect on them. Although a few PFCs do exist in the metropolitan areas, ${ }^{142}$ they are yet to be established at the district level, ${ }^{143}$ despite the order of the Supreme Court issued in $2009 .{ }^{144}$ In such a situation, in spite of rampant violations of food safety laws and numerous casualties caused by unsafe food, consumers are reluctant to go to the ordinary courts mainly because of this excessive delay in the trial procedure and the onerous costs involved in running a case for a long time. To make the judicial remedy effective, in addition to setting up PFCs, judges and lawyers should be trained on this specific area of law and consumers must be given legal right to go to those courts seeking both civil and criminal remedies.

v. Alongside the ineffectiveness of judicial enforcement, the administrative enforcement of consumer laws in Bangladesh is also ineffective. It is widely recognised that a proper and effective regulatory system should be founded on transparency and accountability. ${ }^{145} \mathrm{~A}$ regulatory body should be transparent in policy making, in dealing with relevant issues and in implementing its regulations so that consumers and all other stakeholders keep confidence in

\footnotetext{
${ }^{141}$ See Bdnews24.com Bangladesh, 'HC Asks Govt to Form Food Courts', Bdnews24.com Bangladesh (online), 1 January 2009 <http://dev.bdnews24.com/details.php?id=134274\&cid=2> ('HC Asks Govt to Form Food Courts'); see also 'Government Orders Countrywide Drive Against Food Adulteration: National Food Safety Body Holds Meeting After Five Years, The New Age, Dhaka (24 February 2010) $<$ http://www.newagebd.com/2010/feb/24/nat.html>.

${ }^{142}$ For example, in Dhaka Metropolitan city there is a food court; see, Star Online Report, 'Yunus Gets Bail in Food Adulteration Case', The Daily Star, Dhaka (27 January 2011 $<$ http://www.thedailystar.net/newDesign/latest_news.php?nid=28171>.

${ }^{143}$ Naima Amin, 'Food Court Yet to be Established in Every District', Prothom Alo (online), 14 October 2012 $<$ http://prothom-alo.com/detail/date/2012-10-14/news/297611> [author’s trans].

144 'HC Asks Govt to Form Food Courts', above n 141.

145 See generally Committee to Ensure Safe Food from Production to Consumption, Ensuring Safe Food from Production to Consumption (National Academy Press, Washington DC, 1998) 77.
} 
the regulatory regime. ${ }^{146}$ The fact of widespread corruption practiced by the concerned administrative and regulatory authorities taking advantage of lack of transparency in, and accountability for, their supervision and enforcement actions is believed to be a main reason for the uselessness of these laws. ${ }^{147}$ The regulatory bodies should be accountable for the efficiency and effectiveness of their activities to the higher authorities as well as to the public in general. ${ }^{148}$ The administrative enforcement of food safety laws has been a failure following the serious lack of transparency and accountability of regulatory bodies in Bangladesh. ${ }^{149}$ Regarding consumer right to lodge complaint with the DG under the CRPA 2009 as alluded to earlier, Professor Rahman, said that if the Directorate does not act upon a complaint received from a consumer, the victim will have to pursue the officials and this process will facilitate corruption further. ${ }^{150}$ Perhaps more surprisingly, s62(3) of the CRPA 2009 requires the complainant consumers to pay the costs for scientific examination of the alleged unsafe food. This must be inhibitive for consumers to file a complaint negatively affecting the administrative enforcement to some extent. The multiplicity of regulators and a lack of coordination amongst themselves are also a cause of regulatory failure as mentioned earlier. To make the regulation effective, a graduated approach to regulation called 'responsive regulation' should be put in place in Bangladesh. Ayres and Braithwaite propounded the responsible regulation theory and recommended the regulatory enforcement pyramid of sanctions to regulate the conduct of the regulatees such as food manufacturers, processors

\footnotetext{
146 See generally Organisation of Economic Co-operation and Development (OECD), 'OECD Reviews of Regulatory Reform Australia 2010: Towards A Seamless National Economy' (2010) 106.

${ }^{147}$ See generally Economic and Social Commission for Asia and the Pacific (ESCAP) and Ministry of Finance of the Government of Bangladesh, 'Implementation in Asia and the Pacific of the Brussels Programme of Action for the Least Developed Countries for the Decade 2001-2010: Progress Made, Obstacles Encountered and the Way Forward - Bangladesh' (Paper presented at the High-level Asia-Pacific Policy Dialogue on the Brussels Programme of Action for the Least Developed Countries, Dhaka, Bangladesh, 18-20 January 2010) 12 <http://www.un.org/wcm/webdav/site/ldc/shared/Bangladesh.pdf>.

${ }^{148}$ Hampton ( 2005) abaove n 133, 7, 43.

${ }^{149}$ Ahmed Shafiqul Huque, 'Accountability and Governance: Strengthening Extra-bureaucratic Mechanisms in Bangladesh' (2011) 60(1) International Journal of Productivity and Performance Management 59, 59-60.

${ }^{150}$ Ahmed, above n 122.
} 
and sellers. ${ }^{151}$ The theory posits as a regulatory approach a gradual escalation - from persuasion and motivation at the base of the pyramid, upwards through to civil penalty ${ }^{152}$, criminal penalty, licence suspension as more severe punishments, and finally to licence revocation at the summit of the pyramid, which is regarded as the corporate equivalent to human 'capital punishment'. ${ }^{153}$ The responsible regulation theory is expected to ensure compliance at the base of the pyramid in most cases, and only in few cases escalation to the higher level of pyramid may be necessary where prosecution would be the appropriate remedy. ${ }^{154}$ The present food safety regulatory regime of NSW is grounded on the responsive regulation theory, ${ }^{155}$ and the State has been greatly benefited from this relatively new approach to regulation. ${ }^{156}$

It is therefore submitted that the existing fragmented regal and regulatory regime should be replaced with a consolidated piece of legislation encompassing all relevant issues of food safety, and its administration should be left with a single regulatory body. In reforming the present food safety regime, the international food standards and the regulatory practice of NSW are recommended to be taken into account. At the same time, a PFC should be

\footnotetext{
${ }^{151}$ Ian Ayres and John Braithwaite, Responsive Regulation: Transcending the Deregulation Debate (Oxford University Press, 1992) 35.

${ }^{152}$ Civil penalty is also known as 'fine' (But not in Bangladesh, as in Bangladesh criminal penalties are called as fine as detailed in chapter of the thesis). It is imposed by the courts following the civil court procedures to settle the liability of the wrongdoers and to assess the penalty. Civil penalty is considered as a hybrid of the both civil and criminal laws because the penalty itself purposes to punish the wrongdoers. However, a civil penalty does not include any imprisonment. See Richard Head, 'Company Secretary- The Rise and Rise of Civil Penalties in Australia' (2008) 9 Keeping Good Companies, 518, 518. Therefore, for the purpose of the current study any penalty which embraces the imprisonment will not be considered as civil penalty.

${ }_{153}$ Ayres and Braithwaite, above n 151, 35-6. The pyramid structure of Ayres and Braithwaite also can be found at Bronwen Morgan and Karen Yeung, An Introduction to Law and Regulation: Text and Materials, The Law in Context Series (Cambridge University Press, 2007) 196-7.

${ }^{154}$ David Brown et al, Criminal Laws: Materials and Commentary on Criminal Law and Process of New South Wales (The Federation Press, $5^{\text {th }}$ ed, 2011) 399.

${ }^{155}$ Peter Mascini and Eelco Van Wijk, 'Responsive Regulation at the Dutch Food and Consumer Product Safety Authority: An Empirical Assessment of Assumptions Underlying the Theory' (2009) 3 Regulation \& Governance 27, 27-8, see also Charlotte Wood et al, 'Application of Responsive Regulatory Theory in Australia and Overseas' (Occasional Paper 15, June 2010, Australian National University).

${ }^{156}$ For example, see generally Szabo, Porter and Sahlin, above n 134, 250; Productivity Commission, above n 134, 362; Martin et al, above n 134, 429; Ludlow, above n 134, 184-189; Middledorpm, above n 134, 91; MacKay, above n 134, 900-1.
} 
established at the district level and consumers should be empowered to sue the culprits in competent courts.

\section{Conclusions}

It is a well known proverb that 'we are what we eat" ${ }^{157}$. So, what we are going to get in terms of physical strengths and mental capabilities is, in some way, dependent upon the substance of our food that we eat on a regular basis. Food safety is critical when it comes to the substance. The phrase 'food safety' denotes 'absence or acceptable and safe levels of contaminants, adulterants, naturally occurring toxins or any other substance that may make food injurious to health on an acute or chronic basis'. ${ }^{158}$

The Constitution of Bangladesh declares that 'the Republic shall be a democracy in which fundamental human rights and freedoms and respect for the dignity and worth of the human person shall be guaranteed...., ${ }^{159}$ The right to food is well entrenched in the norms of human rights, and it is also enshrined in the discourse of social rights. ${ }^{160}$ The consumption of safe food is a fundamental as well as international human right as alluded to earlier. The foregoing discussion reveals that the Government of Bangladesh is under legal obligation to ensure the enjoyment of the RLRF by providing food safety in the country. Nonetheless, food adulteration and the consumption of poisonous foodstuffs are rampant with almost complete impunity. The consequences are obviously fatal, which include deaths, disabilities, terminal diseases and appalling sufferings of human beings. The government does not seem to be serious about such a life threatening issue. The government is obliged to ensure safety of life

\footnotetext{
157 Anonymous, 'Nutrition - We are What We Eat' The Economist (4 Sep 2003) $<$ http://www.economist.com/node/2020047/print > (19 April 2013).

158 FAO, 'The Importance of Food Quality and Safety for Developing Countries' $<$ http://www.fao.org/trade/docs/LDC-foodqual_en.htm> (19 April 2013).

159 The Constitution of the Peoples Republic of Bangladesh 1972, art 11.

160 See, for detailed discussions, David Landau, 'The Reality of Social Rights Enforcement' (2012) 53(1) Harvard International Law Journal 189; Audrey R. Chapman and Benjamin Carbonetti, 'Human Rights Protections for Vulnerable and Disadvantaged Groups: The Contributions of the UN Committee on Economic, Social and Cultural Rights'(2011) 33(3) Human Rights Quarterly 682.
} 
of the public and will have to primarily shoulder all the failures to prevent harm of its people. It is submitted that the gravity of the issue deserves to be addressed with due emphasis before it becomes too murky and intractable. It has to be dealt with by the government under an appropriate legal and regulatory regime which is currently absent in Bangladesh as briefly discussed above. However, for a guideline, the national laws concerning food safety in industrial and developing countries alike must demonstrate the will of the government to protect their citizens from unsafe and adulterated foods, and the law should be founded on a common basic provision which reads: '[a]ny person who sells to the prejudice of the purchaser any food which is not of the nature or is not of the substance, or is not of the quality of the food demanded by the purchaser, shall be guilty of an offence ...., ${ }^{161}$ The desired safety can be achieved through taking timely and appropriate measures to control foodstuffs and those measures should be founded on well-defined food regulations encompassing aspects of quality and safety of food and its honest presentation to consumers as a general rule. As suggested above the existing legal and regulatory regime ${ }^{162}$ should be reformed in light of the international standards and the regulatory practice of NSW, while special courts for food related cases should be established given the special circumstances in Bangladesh as required by PFO 1959 and directed by the Supreme Court.

However, the regulation of food adulterants alone may not be sufficient to achieve an enduring success, consumers need to be made aware of and educated about the terrible impacts of adulterated foods for human health and lives. To this end, an essay on food safety and the harmful effects of unsafe foods can be included in school curricula, and simultaneously the electronic and press media like radio, television and newspapers can play a pivotal role in creating such awareness. Appropriate and immediate measures need to be

\footnotetext{
161 FAO, 'The Importance of Food Quality and Safety for Developing Countries' $<$ http://www.fao.org/trade/docs/LDC-foodqual_en.htm> (last accessed 21 May 2013).

${ }^{162}$ A detailed discussion of the existing legal and regulatory framework for food safety regulation in Bangladesh is beyond the scope of this article and it will be the task in another piece.
} 
taken to weaken both the demand and supply sides of poisonous foods in order to achieve an effective food control and protection of the RLRF in Bangladesh. 